\title{
Moscow as international financial center: ideas, plans and perspectives.
}

\author{
Sherstnev M.A. ${ }^{10}$, Abramov D.V. ${ }^{11}$, Polezhaev S.A. ${ }^{12}$
}

The paper provides an overview of the Russian official plans of development of the international financial center (based primarily in Moscow) and tries to stimulate the discussion on the critical assessment of the perspectives in order to outline the efficient ways to achieve this ambitious goal.

JEL: G150, G290

Key words: Moscow, international financial center, Russian banking system, bank taxation

\section{Introduction}

In the course of market transformation of the Russian Federation the country faces the big challenge of integration in the global economy. One aspect of such integration is the full-scale participation in the world financial system. The country has already done a lot in this direction both the government and the private sector. High rates of economic growth in the 2000 s created the new opportunities for financial development in Russia via high liquidity from the boom at commodities markets and inflows of private capital. Russia accumulated substantial international reserves and sovereign wealth funds which should be invested and efficiently managed.

Moscow has firmly established itself as the national financial center of the country which concentrates the bulk of the financial industry and of the financial flows. However from the international perspective the country is still dependent from the global international financial centers - primarily London and New York, then Frankfurt and now Hong Kong - with regard to big financial business (IPOs, medium to long term borrowings via syndications and Eurobonds, important M\&A transactions). Moscow is still placed very low by the Corporation of London research team in the Global Financial Centers' Index. Therefore the Russian authorities put forward the task to develop the Russian financial center of international standing which should be based in Moscow and probably later partially in St. Petersburg.

\section{Official plans of the Russian authorities}

The goal of development in the Russian Federation of the new international financial center was put forward by President Dmitry Medvedev in his first Presidential Address to the Federal Assembly of the Russian Federation in November 2008. Following the outbreak of the global economic and financial crisis the Russian authorities expressed the intention to open the new opportunities for financial innovation in Russia and try to increase the role of Russian ruble in the international settlements $(4 ; 5 ; 6)$.

The starting point of official thinking is based on the view that Russia faces the dilemma: either it develops the financial market in line with the international standards and integrates it into the global financial market as one of its important parts or it loses the national financial market at

\footnotetext{
${ }^{10}$ Associate Professor of Theoretical Economics and International Economic Relations Department, Samara State Economic University

${ }^{11}$ Senior Lecturer of Theoretical Economics and International Economic Relations Department, Samara State Economic University

${ }^{12}$ The graduating student of Theoretical Economics and International Economic Relations Department, Samara State Economic University
} 
all since the majority of financial transactions (including those of the Russian residents) move to other financial centers.

The official documents specify the following pre-requisites for the development of Russian international financial center:

- the large size of the national economy and its dynamic nature which should potentially create demand for the financial services;

- the high level of human capital which could be used in the financial services industry (since Russia has high level of education in mathematics, computer science, engineering and natural sciences the people with such educational background should be able successfully employ their skills in the most advanced areas of modern finance);

- the geographical location of Moscow between the European and Asian financial centers;

- relatively high level of development of national financial market which already trades number of financial instruments including many derivatives, has two exchanges;

- relatively close links with CIS countries and the absence of language barriers which opens the door for access of securities from those countries to the financial center in Russia.

The principal challenges on this way are seen by Russian authorities as follows.

First, Russia should further develop its legislation and regulatory framework for financial markets and financial transactions. The most urgent laws which should be approved and implemented are those on exchanges, clearing, securitization and anti-inside measures. The Russian legislation should also be developed with regard to derivatives, collaterals, infrastructure of the financial markets.

The development of financial center in Russia requires substantial development of national tax legislation and further improvement in tax administration. The functioning of the financial market is interlinked with the stability of property rights and the system of corporate governance.

Second, Russian authorities find it important to stimulate the further development of the national market in terms of both variety and sophistication of financial instruments and financial market infrastructure. The wide range of measures includes such steps as IPOs in Russia, increase of free-float of shares of Russian companies (including those with the government controlling stake).

Third, the Russian financial market should be gradually integrated in the global capital market. The foreign participants should get access to the Russian financial market, in particular, to exchanges more easily. At the moment such access is possible via two regimes - either registration of issue under Russian law or Russian depository receipts (RDRs). The Russian authorities don't see any distinctive advantage of any of these regimes and therefore are going to promote both of them.

At the moment, however, in order to trade at the Russian exchanges the foreign participants are required to register the legal entity under the Russian civil legislation and obtain the license of the professional participant of the securities market (otherwise they have to use the service of brokers). In the age of Internet and sophisticated IT this may create obstacles for foreign participants who wish to get the direct access to the Russian exchanges from their offshore offices and therefore undermine the competitiveness of Russia in the global financial market. The possible solution might be to grant the licenses of the professional participants to certain types of institutional investors which meet the requirements of the Russian legislation so that they escape the establishment of Russian subsidiaries.

Fourth, certain steps should be taken to provide the qualified personnel for the financial center. It's necessary to improve the quality of education in economics and finance in accordance with the modern international standards since at the moment only several advanced higher education institutions provide training of international standing. At the same time Russia needs to make easier immigration of foreign specialists and make steps to further improve quality of life in Moscow (rental costs, transportation, English-speaking personnel, etc.).

The Russian official documents set the following targets for the medium-term perspectives (up to 2012): 
- one of the Russian exchanged should be in top 12 exchanges in the world;

- the share of foreign securities at the Russian exchanges should be not less than $10 \%$ in terms of turnover;

- the share of financial sector to GDP should rise to $6 \%$;

The further impetus to the project was done by President Medvedev in April 2010 when he had the special meeting with leading foreign financiers doing business in Russia and Russian officials in charge of economy and finance. The special task force led by former Chief of Presidential Administration and current Chairman of Board of Norilsk Nickel Alexander Voloshin was established to facilitate the legislative and regulatory changes and maintain the dialogue with the market actors.

\section{Russia in international finance}

The main features of Russia's financial international links by the start of the global economic and financial crisis could be described as follows. First, Russia accumulated the third largest foreign currency reserves in the world (after China and Japan) which mounted to $582 \mathrm{bln}$. USD at September 1, 2008 (Central Bank of Russia). The high energy and raw material prices allowed the Russian government to improve substantially the state of public finances, reduce the level of foreign debt and accumulate substantial reserves in the Reserve and National Wellbeing Funds. Second, the Russian financial institutions and non-financial companies substantially increased their presence at the world financial markets via both share issuance (including IPOs) and borrowings. This caused the sharp increase of the foreign debt obligations of the Russian private sector especially in the period of 2005-2008.

The evolution of the international investment position of the Russian Federation is shown below.

Table 1

International Investment Position of the Russian Federation, 2001-2009 (mln.USD)

\begin{tabular}{|l|l|l|l|l|l|l|l|l|}
\hline & 2001 & 2002 & 2003 & 2004 & 2005 & 2006 & 2007 & 2008 \\
\hline Assets & 248752 & 259498 & 288480 & 336825 & 406635 & 516412 & 731590 & 1099335 \\
\hline Liabilities & 184207 & 215587 & 251301 & 332901 & 417270 & 547860 & 770133 & 1244651 \\
\hline Net IIP & 64545 & 43911 & 37179 & 3924 & -10635 & -31448 & -38544 & -145316 \\
\hline
\end{tabular}

Source: Central Bank of Russia

The data shows the significant increase of the Russian involvement in the global finance.

\section{Russian banking system: difficult ways of development}

The commercial banking system turned out to be the first sector of the financial system which developed in the course of the market transformation in the Russian Federation (13). This trend was characteristic for all transition economies and lies in line with more general trends of financial development in the world economy. The financial market is characterized by the informational imperfections (e.g. information asymmetry) which require development of certain institutional arrangements and regulatory regimes to allow them to function properly (17).

The development of Russian banking system was subject to numerous criticisms in the past years. However its worth to notice that the development path of the banking system in Russia followed the same pattern as that of more advanced transition economies (Poland, Hungary and Czech Republic) but with less involvement of foreign financial institutions. Russia managed to develop its national banking system which withstood both liquidity and systemic crises in the last nearly two decades and rebuilt itself in the post-crisis periods.

The distinctive features of the Russian banking system are:

- the large number of the credit organizations; 
- the small size of the banking system relative to the economy.

These features really give ground for doubts on the capabilities of such system to perform all functions of financial intermediation in the growing economy and were the milestones of critical remarks of observers and researchers. However the available data shows that the conventional financial depth indicators of the Russian banking system steadily increased in the course of market transformation (20). The increasing sophistication of the banking system in Russia which now offers wide range of services to both companies and private individuals forms the solid basis for further integration of the sector in the global financial market. At the same time these opportunities requires further critical assessment which is provided below.

\section{The Russian banking system as part of international financial center: how realistic?}

Talking about banking system we must remember that it is only a transmitter, an economy pump for forcing investment, savings, and money funds and for transforming them. Such a system helps to create an interconnection between government (an emission centre and regulator), nonfinancial economy, financial market and general public. These connections should bring effective and rational economic growth, balanced economic structure, innovative development and rise in standard of living. That's why banking system status can tell us about the development of the whole economy. From this perspective we can state that Russian economy is seriously ill. Its heart - banking system - doesn't answer the purpose of economy modernization and positioning the Russian Federation as one of the global financial centers and economic leaders.

For better understanding first we will determine the opportunities of the Russian Federation both existing and potential, afterwards we will emphasize obstacles on the formation of powerful international financial center in Russia. Let's make a reservation: the only megalopolis to be such a center is Moscow (64\% Russian banking assets), other big Russian cities are not able to compete with Moscow and Russian officials have no plans of creation artificial megalopolis. We should also mention that we will take into consideration only banking system, because non-bank financial institutions in Russia are undeveloped and have no real influence on the economy. Therefore it's impossible (at least until a powerful banking system will be formed) to enter the global financial market and to occupy an advantage-ground with such institutions (investment funds, pension funds, insurance companies).

Opportunities:

1) The Russian Federation attained status in geopolitical and geoeconomical space.

Russia as an active member of G8, G20, World Bank, Paris Club of Creditors, FATF, APEC, BRIC and others international organizations. This constructs the necessary institutional environment for the future international financial center.

2) Significant factors of national wealth - background of banking system's generating.

Expert judgements show that nowadays Russia uses its national wealth only by $8-10 \%$. It includes rich deposits of mineral wealth, land, agricultural holding, real estate and intellectual property. If all these resources are involved in financial turnover particularly with the help of pledge mechanism used when crediting and issuing money supply, banking system will be able to raise its assets promoting qualitative economic growth of the whole country.

3) Favorable macroeconomic and financial situation in the country.

Brief description of the favorable situation:

- available considerable gold and exchange currency reserves (448,6 billon \$ on 15 April 2010);

- huge amount of state savings (about $\$ 190$ billion) (2, table10);

- effective and consistent government policy: budgetary and fiscal, monetary and financial, capital flow regulations;

- permanent reduction of bank rate and inflation controls (Central bank inflation forecast $6,5-7,5 \%$ in 2010) (2, table 10) (7); 
- relatively stable rate of exchange has sturdy consolidation factors; opportunity of transforming Russian oil and gas payments into rubles, creation of the raw materials exchanges (first - oil exchange in Saint-Petersburg) and movement towards free convertibility of rubles; possible creation of ruble zone in CIS countries and use of rubles as means of payment in BRIC;

- good perspectives of private banking (the rich Russians have 300-350 billon\$) (14).

In 2009 in spite of crisis Russian banking system resisted in many respects owing to proactive government intervention particularly Central bank that allotted unsecured credits. Central bank efficiency is performed not only by stabilized system, but also by its income on such credits - about 200 billion rubles (net profit of all Russian banking system in $2009-205$ billion rubles) (17, p. 47). According to the Head of Central Bank Sergey Ignatiev the banking system is being restored and nowadays it has no serious system risks.

4) Foundation of significant universal state banks (banks with primary state interest) Sberbank, VTB group, Rosselhozbank, Gazprombank.

These state banks form the base of Russian banking system; they own significant capital and assets together with confidence. Sberbank and VTB carried out successful IPO, actively enter the world money-market and market of capitals, carry out direct investment in foreign markets, including acquisition of non-financial assets. Listed Russian banks are able to compete with the key transnational banks from developed countries. Besides government plans VEB IPO together with other development banks which today are state corporations.

5) Pent-up potential demand for bankroll from the direction of nonfinancial sector under the circumstances of essential thorough modernization of Russian economy and capital renewals.

President Medvedev declared this problem issue of the day for our economy. Banking system together with public and foreign investments at this juncture is supposed to become basic funding source while such sources as profit, depreciation and portfolio investment within the next 5-10 years right up to 2020 won't be of great importance in the investment process. In this case appeal of Russian market for transnational banks of USA, France, United Kingdom, Switzerland, Italy and others is obvious.

6) Intense interest of first-rate world private banks in Russian credit market.

Number and weight of non-residents in Russian banking system permanently increases and at the end of 2009 makes up $24,53 \%$.

Of course, mentioned opportunities do not represent complete set, we emphasized only those of vital importance from our point of view.

Now let's turn to obstacles. They are greater and more serious than opportunities because they have already not potential but chronic substance starting with transfer Russian economy to market system in 1990s. All obstacles we may divide into external and exceptionally internal obstacles.

Major external obstacle is a global financial crisis. Last time Russia felt already two shocks 1998 and 2009 years. In 1998 our economy and its financial system found itself on the verge of collapse and default, however in 2008-2009, as shown Central Bank statistics and forecasting information of World Bank, Russian financial system held out and came to stronger than industrial and human services sectors of economy. As some world-famed analysts mentioned, Russia has come out of crisis and become stronger than before. In many respects it is become possible owing to accumulated state funds and reserves and weak dependence of Russian financial market from portfolio investment, derivatives and compound financial instruments. On the one hand, this situation deprive Russia many financial shakes, and downfall of Russian stock market and ruble devaluation related first of all to falling down of oil prices. Russian financial market and economy have fallen deeper than any global key countries (financial market approximately on 30\%, economy on 7,1\%), but have shown faster recovery (for example, capitalization of Russian stock market has doubled in 2009; in 2010 increase of MICEX index will expected at the rate of 15-25\%). Russian market and economy have shown us an extreme volatility. Even during last months the forecast concerning Russian economic growth are being constantly revising towards increasing. At the beginning of February it has been about $2 \%$, but now, at the end of April, the official forecast of 
Ministry of Economic Development is 3,1\%; but in opinion of the Head of Citigroup in Russia and CIS countries Zdenek Turek it's already 5-6\% (19). S\&P has revised the long-term rating changes forecast from "negative" to "stable" for 14 Russian financial institutes recording the stabilization of their business conditions and going through the peak of non performing loans (according to Reuters from 1 April 2010).

We may be glad to it. But in our opinion the last crisis has shown the weakness of Russian economy, first of all in financial sphere and banking system, which couldn't support industrial sector (downfall of industrial production in 2009 - 19,8\%). Banking system was obliged to stay with extended hand to Central Bank and Government itself. As mentioned S\&P, in spite of positive movements the process of recovering banking sector in Russia will be long and will take at the least 2 years. But on the whole, it will be well to note that Russian Government found out a certain maturity at the fight against consequences of global financial crisis. Reserves were used correctly although it has lead to lowering the living standards of large quantity of Russian citizens. As an example, for the welfare of banking system only in aspect of operations with credit instruments there were spent 785 billion rubles of the state budget, at that time all budget expenditures for provision of pensions in 2009 were 275 billion rubles and for recapitalization of banks there were directed only 75 billion rubles (15).

Now let's turn to internal obstacles, which cannot allow creating in Russia international financial centre.

Internal obstacles.

1) Excess dependence of banking system from state banks.

This dependence can break the development of private banking sector and direct credit resources to inefficient and state-controlled firms.

2) Big share of bad debts (non performing loans) and overcrediting of Russian borrowers.

By assessment of S\&P bad credits amount 40\% over the banking system (coupled with restructuring credits). As a result of this the agency expects the rising of credit portfolio in 2010 on a level of about 10\% (16), although the Head of Central Bank Sergey Ignatiev are expecting 15\%.

3) The absence in Russia remarkable investment banking sector.

One might that on a global financial scale the Russian investment banking sector is absent. On the one hand, Russian Government has not to puzzle over the decoupling of commercial banking and investment banking, not to feel direct consequences of crisis by way of failure of national investment banks. On the other hand, without remarkable investment banking the transformation of Russia into international financial centre is impossible.

4) Poor development of institutional investors and lack of wide range of financial instruments in Russia.

Unfortunately, in Russian financial market the part of investment funds, pension funds and insurance companies is utterly small (about 10-15\%). It hampers for allocation of household's savings and transformation them to the investment resources. At the same time the lack of many contemporary financial instruments and small number of security's issuers are leading to that Russian market is not attractive for global portfolio investors. Russian financial market is entirely oriented on raw materials sector, energy and communication (10 first-rate issuers, which has occupied $80 \%$ of the market).

5) Low level of household's savings, distrust for financial institutes and stagnation of consumption.

Households actively invest in real estate overheating the market; or in foreign currency which lead to withdrawal these funds from national investment process. The number of households which have securities or shares in investment funds amount $8-10 \%$. Banking system remains a sole alternative to consumption and quasi-investment demand, but household's savings are decreasing ( $25 \%$ of households has bank deposits - about $10 \%$ of all household's incomes) because of low incomes (average wages - 6500-7000\$ per year) and low yield on savings deposits (keep within inflation). 
In conclusion, to sum up we can say that there are no chances for Russia to create an international financial centre before 2020. In the best case it'll be possible to form a regional financial centre for CIS and East Europe. The majority of opportunities are potential, and our society, business and The Government must work day-by-day, roll up the sleeves and to get down to work in order to transform potential into reality. As mentioned Joseph Eugene Stiglitz, the objective is not to simply create strong healthy banks, it is necessary to create strong healthy banks which credit the economic growth. As an example, Argentina has shown that inability to do this can lead to macro instability in itself. Russia has no the right to do something similar.

\section{Bank taxation in Russia: pains and possible remedies}

Development of effective financial infrastructure within the concept of international financial center in the Russian Federation contemplates a reform of tax rules and procedures in respect of financial institutions, in particular, of the banks. At present there exist a number of issues of bank taxation that have a negative impact on the Russian banking system ${ }^{13}$ :

First, in the opinion of majority of Russian economists, the main problem of bank taxation is an absence of effective mechanism that can stimulate banks to invest in a real sector of economy. Solution of this problem will gain a taxable capacity of economy, certain regions and industries, increase banking industry assets, enhance income of banks that will ultimately result in extra tax revenues received by Russia's budget system.

Second, it is essential to amend the tax procedure of recognising an interest income on overdue loans originated by banks. The question at issue is a continuation of interest accrual in tax accounting on credits originated by the banks, even if the borrowers have stopped to return loans and pay interest. According to that, a tax charges on uncollected profit and effective banks yield decreases. There exist a number of methods to stop accrual of interest on overdue loans in tax accounting of credit organization, but each of them has its own disadvantages and is difficult to perform.

Third, thin capitalization issues can arise only in the following cases according to Russian tax legislation: a company (bank) attracts a loan from foreign shareholders (as well as their Russian affiliates, or loans guaranteed by foreign shareholders or their Russian affiliates) owning more than $20 \%$ of its capital. But in practice companies attract loans from foreign companies belonging to the same group which are not direct or indirect shareholders, so these loans do not technically fall under thin capitalization regulation. However, interest on such loans may be challenged by the tax authorities based on the "substance over form" approach. This often results in tax disputes and legal proceedings between tax authorities and taxpayers.

Fourth, trading of precious stones and metals in the form of ingots by banks to legal entities and individuals is a subject to VAT. Tax legislation of the RF provides VAT exemption of precious metals sale by banks only in case of placing of purchased ingots to the metals account of the selling bank, but the exemption is cancelled when carrying out a physical transaction with the precious metal purchased to the account. This suppresses a development of domestic physical precious metals market that is an instrument of currency risks hedging and making profits (e.g., in case of arbitrage and exchange transactions) for the investors.

\section{Conclusion}

The development of the international financial center in the Russian Federation - the goal which was set by President Dmitry Medvedev - is really a big challenge. Though the Russian government put the concise program its practical implementation faces serious difficulties. The project of such scale and scope affects various sides of the functioning of the public and private sectors.

\footnotetext{
${ }^{13}$ The discussion in based on $(3 ; 8 ; 10 ; 11 ; 18)$
} 
The most important obstacle is the insufficient level of financial development in the Russian Federation. Even the Russian banking system - the most advanced part of the national financial industry - provides less intermediation than its counterparts in developed and advanced emerging economies. Other sectors of financial industry - especially those providing the vehicles for long term saving and financing - are even less developed. The other obstacle is the low level of public services and public administration (including corrupt practices of all level of state bureaucracy) which is the big issue for the whole Russian society.

However the 2000s allows also looking with some optimism for the project. Gradually Russian financial sector is developing and increasing its technical and instrumental sophistication. Russian government and business become more and more involved in the international financial markets - both as creditors (investors) and borrowers. There is no doubt that the commitment to such ambitious goal will have its own positive impact of the further financial development in Russia and the arrival of serious big international business will put new level of discipline on both national business practices and national administration.

\section{References}

1. Central Bank of the Russian Federation (www.cbr.ru)

2. Conception of Russian financial market development before 2020. Joint project of Rating agency "Expert RA" and the Association of Russian regional banks. Realized under the $\begin{array}{llllll}\text { aegis of } & \text { Public } & \text { Chamber }\end{array}$ http://www.raexpert.ru/strategy/conception/part2/4/

3. Goncharenko, L. Bank operations with precious metals. Problems of taxation and VAT exemption. Tax policy and practice, 2008, № 9

4. Government of the Russian Federation "Strategy of the Development of the Financial Market of the Russian Federation for the Period up to 2020".

5. Government of the Russian Federation "Concept of the Establishment of the International Financial Center in the Russian Federation".

6. Government of the Russian Federation "Action Plan for the Establishment of the International Financial Center in the Russian Federation".

7. Ignatiev: inflation in 2010 amount 6, $5-7,5 \% / /$ Vedomosti, 9 April 2010. www.vedomosti.ru/newsline/news/2010/04/09/988954

8. Ignatova, N. Directions of development of certain operations in bank taxation. Financial newspaper, 2008, № 40

9. International Monetary Fund, World Economic Outlook Database

10. Kalakov, R. Tax stimulation of lending for innovative activity. Taxes and taxation, 2008, № 6

11. Safonova, T., Zhukova, J. Taxation of overdue loans. Taxation, accounting and financial reporting in commercial bank, 2010, № 1 .

12. Sherstnev, M. (2009) "Russian Banking in Transition: Survey and Synthesis" in: Credit, Currency, or Derivatives: Instruments of Global Financial Stability or Crisis? International Finance Review, Vol. 10, 215-262

13. Skogoreva, A. Private banking in Russia are rising on one third annually// Banking Review, №2, February 2006, Moscow.

14. Sokolov, A. Banks: risks and bad debts// Vedomosti, 242 (2512), 22 December 2009. www.vedomosti.ru/newsline/article/2009/12/22/229544

15. S\&P see the stabilization in Russian banks (according to Reuters)// Vedomosti, 1 April 2010. www.vedomosti.ru/newsline/news/2010/04/01/983064

16. State of Russian banking sector in 2009// Bulletin of the Bank of Russia, №16 (1185), 17 March 2010, Moscow

17. Stiglitz J., Greenwald, B. (2003) "Towards a New Paradigm in Monetary Economics", Cambridge, Cambridge University Press 
18. Tax Code of the Russian Federation

19. Zdenek Turek: Soon banks will start to compete for good clients with// Money, №11 (766), 22 March 2010. http://www.kommersant.ru/doc.aspx?DocsID=1334976

20. World Bank, Financial Development and Structure Database 